Економічні науки: збірник наукових прачь Луцького національного технічного університету. - Серія "Регіональна економіка". - Випуск 16 (63). - Редкол.: відп. ред. д.е.н., професор Л.Л. Ковальська - Луиьк: ІВВ Луцького НТУ, 2019. - 173 с.

УДК 332:352:502

Волинчук Ю.В., к.е.н., доцент

Камінська I.M., к.е.н., доцент

Луцький національний технічний університет

\title{
СТАЛИЙ РОЗВИТОК ВОЛИНІ: ЦІЛЬОВІ ОРІЄНТИРИ
}

В статті розглянуто цілі сталого розвитку, визначені як пріоритетні для Волинської області до 2030 року. Проаналізовано ключові завдання для досягнення поставлених цілей та основні характерні індикатори. Наведено рекомендації, що сприятимуть збалансуванню зазначених цілей в регіоні.

Ключові слова: сталий розвиток, цілі, завдання, Волинська область.

Volynchuk Yu.V., Kaminska I.M.

SUISTAINABLE DEVELOPMENT GOALS OF THE VOLYN REGION

Ensuring sustainable development is a global imperative and this issue is particularly relevant to Ukraine in view of economic, social and environmental challenges currently facing the country. Sustainable development goals are discussed in the article and all the goals are identified as priorities goals for Volyn Region until the year 2030. Key tasks for implementation of the set of goals and main indicators are analyzed. A set of realistic recommendations that will help to balance all the goals in the region are determined.

Volyn Region was one of the first regions in Ukraine which adapted the National Sustainable Development Goals Report to the regional level. Volyn Region should give high priority to the following five goals: goal 3 -good human health and well-being; goal 8 - decent work and economic growth; goal 9 - industry, innovation, infrastructure; goal 15 - life on land (protect and restore life on land); goal 16 - peace, justice and strong institutions. Action plans, targets and indicators were developed for each of these goals. Based on the analysis, it was determined that raising the level of employment, including self-employed in medium and small businesses, could give a serious impetus for developing of Volyn Region.

In the context of need to balance the environmental and economic goals of sustainable development, the task of reducing the area of arable land in the total territory of the region while at the same time increasing the agricultural potential of the region seems not an easy task. The intensification of the organic farming rather than the traditional farming is another one interesting trend in modern conditions. Such way of running business attracts specialized agricultural enterprises of Volyn region. However, it has been proved that according to a climatic point of view, organic agriculture and biofuels production and further use are not effective in Volyn region. 
Економічні науки: збірник наукових праць Луцького національного технічного університету. - Серія "Регіональна економіка". - Випуск 16 (63). - Редкол.: відп. ред. д.е.н., професор Л.Л. Ковальська - Луиьк: ІВВ Луиького НТУ, 2019. - 173 с.

In order to ensure balanced implementation of the tasks and to achieve the goals of sustainable development, involving the leading regional higher education institutions in providing information, educational and expert consulting services is a strategically important step.

Key words: sustainable development, goals, objectives, Volyn region.

Волынчук Ю.В., Каминская И.Н.

\section{УСТОЙЧИВОЕ РАЗВИТИЕ ВОЛЫНСКОЙ ОБЛАСТИ: ЦЕЛЕВЫЕ ОРИЕНТИРЫ}

В статье рассмотрены цели устойчивого развития, определены как приоритетные для Волынской области до 2030 года. Проанализированы ключевые задачи для достижения поставленных целей и основные характерные индикаторы. Приведены рекомендации, способствующие сбалансированию указанных целей в регионе.

Ключевые слова: устойчивое развитие, цели, задачи, Волынская область.

Постановка проблеми у загальному вигляді та її зв'язок 3 важливими науковими та практичними завданнями. Забезпечення сталого розвитку $є$ глобальним імперативом та особливо актуалізується для України з огляду на економічні, соціальні та екологічні виклики, що постають перед нею. Указом Президента України у вересні 2019 року встановлено, що «Цілі сталого розвитку України на період до 2030 року є орієнтирами для розроблення проектів прогнозних i програмних документів, проектів нормативно-правових актів 3 метою забезпечення збалансованості економічного, соціального та екологічного вимірів сталого розвитку України» [1].

Сталий розвиток - це розвиток, що відповідає потребам сучасності, не впливаючи на здатність майбутніх поколінь задовольняти свої власні потреби. Сталий розвиток вимагає узгоджених зусиль щодо створення всеосяжного, сталого та стійкого майбутнього для людей та планети. Для досягнення сталого розвитку надзвичайно важливо гармонізувати три основні елементи: економічне зростання, соціальну інтеграцію та охорону навколишнього середовища. Ці елементи взаємопов'язані, і всі вони мають вирішальне значення для 
Економічні науки: збірник наукових прачь Луцького національного технічного університету. - Серія "Регіональна економіка". - Випуск 16 (63). - Редкол.: відп. ред. д.е.н., професор Л.Л. Ковальська - Луцьк: ІВВ Луцького НТУ, 2019. - 173 с.

добробуту окремих людей та суспільств.

Викорінення бідності у всіх іiі формах та на всіх рівнях $€$ неодмінною вимогою для сталого розвитку. Для досягнення цієї мети необхідно сприяти сталому, всеохоплюючому та рівноправному економічному зростанню, яке б створювало більші можливості для всіх, зменшувало нерівності, підвищувало базові стандарти життя, сприяло справедливому соціальному розвитку та включенню, а також інтегрованому та сталому управлінню природними ресурсами та екосистемами

Аналіз останніх досліджень, у яких започатковано вирішення проблеми. Дослідженню процесів сталого розвитку присвячені наукові праці відомих іноземних та вітчизняних вчених, серед яких Б. Большаков, Л. Мельник, М. Згуровський, В. Скотт, А. Садовенко, В. Данілов-Данільян, О. Кузнєцов тощо.

Волинь стала однією 3 перших областей України, що прийняли рішення адаптувати Національну доповідь щодо Цілей Сталого Розвитку [2] на регіональному рівні. Регіональна доповідь «Цілі Сталого Розвитку: Волинь» є фундаментом змін стратегії розвитку області на період до 2030 року [3]. На національному рівні моніторинг досягнення цілей і виконання завдань щорічно здійснюється у відповідному Звіті [4].

Цілями статті, зважаючи на викладене вище, є дослідження та аналіз цільових орієнтирів сталого розвитку Волинської області.

Виклад основного матеріалу дослідження 3 повним обгрунтуванням отриманих наукових результатів. Досягнення цілей сталого розвитку залежить від спроможності регіональних i місцевих органів влади підтримувати інтегрований, інклюзивний та сталий розвиток територій. Першочергову увагу на Волині планується зосередити на таких 5 цілях:

- ціль 3 - міцне здоров'я та благополуччя;

- ціль 8 - гідна праця та економічне зростання;

- ціль 9 - промисловість, інноваціі, інфраструктура;

- ціль 15 - захист та відновлення екосистем суші;

- ціль 16 - мир, справедливість та сильні інститути.

Оскільки саме ці цілі визначено пріоритетними для Волинського регіону, то розглянемо більш детально їх за 
Економічні науки: збірник наукових праџь Луцького національного технічного університету. - Серія "Регіональна економіка". - Випуск 16 (63). - Редкол.: відп. ред. д.е.н., професор Л.Л. Ковальська - Луцьк: ІВВ Луцького НТУ, 2019. - 173 с.

складовими в розрізі поставлених завдань та індикаторів.

Ціль 3 - міцне здоров'я та благополуччя передбачає забезпечення здорового способу життя та сприяння благополуччю для всіх у будь-якому віці. Найвагомішим при цьому $є$ аналіз завдань, що характеризують зниження материнської смертності, хворих на ВІЛ/СНІД, туберкульоз та інші неінфекційні захворювання. На жаль, в регіоні кількість хворих 3 діагнозом туберкульоз, встановленим вперше у житті, $\epsilon$ високою і перевищує загальнодержавні показники (62,8 осіб на 100000 населення і 55,9 осіб відповідно), тому цей аспект насправді дуже проблемний. 3 кожним роком зростає показник захворюваності на СНІД та ВІЛ-інфекцію, що пояснюється значною міграцією населення, зниженням якості диспансеризації населення, низькою відповідальність населення за своє здоров'я, низькою платіжною спроможністю населення. Люди звертаються за медичною допомогою вже на запущених стадіях захворювання.

На жаль, не винесено на регіональний моніторинг завдання із підвищення імунізації згідно з Календарем профілактичних щеплень до визначених шести вікових груп при профілактиці основних десяти інфекційних захворювань та зниження поширеності тютюнокуріння серед населення. 3 іншого боку, очікується підвищення доступу населення до якісних медичних послуг через подальше зростання виділених коштів на охорону здоров'я в обласному бюджеті (з 44\% у 2015 р. до $50 \%$ у 2020 р.).

3 метою вирішення цих проблем в області розпочата реформа системи первинної медичної допомоги, формування спроможної мережі закладів первинного рівня надання медичної допомоги на засадах загальної практики / сімейної медицини, що вирішить питання доступності медичної допомоги населенню. Первинна медична допомога оплачуватиметься Національною службою здоров'я, що уможливить своєчасне та якісне надання такої допомоги. Необхідно також покращити якість диспансеризації населення та підвищити відповідальність населення за своє здоров'я. Зокрема, посилити роботу первинної 
Економічні науки: збірник наукових праць Луцького національного технічного університету. - Серія "Регіональна економіка". - Випуск 16 (63). - Редкол.: відп. ред. д.е.н., професор Л.Л. Ковальська - Луцьк: ІВВ Луцького НТУ, 2019. - 173 с.

медико-санітарної ланки з жінками дітородного віку в частині інформування про перебіг вагітності, пологів; забезпечити широке інформування молоді про небезпеку інфікування хворобами, що передаються статевим шляхом тощо.

Ціль 8 - гідна праця та економічне зростання в розгорнутому розумінні передбачає сприяння поступальному, всеохоплюючому та сталому економічному зростанню, повній i продуктивній зайнятості та гідній праці для всіх жителів регіону. Серед завдань при цьому, насамперед, забезпечити стійке зростання ВВП на основі модернізації виробництва, розвитку інновацій, підвищення експортного потенціалу, виводу на зовнішні ринки продукції 3 високою часткою доданої вартості.

Розглянемо індекс фізичного обсягу ВРП у цінах попереднього року на Волині. У 2015 р. він становив 95,6\% (індекс фізичного обсягу ВВП в Україні у 2015 р. 90,2\%) з цільовим орієнтиром на 2020 р. у розмірі $101 \%$ і на 2030 р. у розмірі $105 \%$.

Частка експорту товарів 3 використанням у виробництві технологій високого та середньо високого рівня в загальному обсязі експорту товарів на Волині у 2015 р. становила 48,3\% (в Україні - 19,2\% зі скороченням до 17\% у 2017 р.) 3 цільовим орієнтиром у розмірі 52\% у 2020 р. і $57 \%$ у 2030 р. Сюди належать такі групи товарів: «Продукція хімічної та пов'язаних 3 нею галузей промисловості», «Полімерні матеріали, пластмаси та вироби 3 них», «Машини, обладнання та механізми; електротехнічне обладнання», «Засоби наземного транспорту, літальні апарати, плавучі засоби», 90-та підгрупа групи «Прилади та апарати оптичні, фотографічні» згідно УКТЗЕД. Впровадження технологічних інновацій дає змогу підприємствам оновити продукцію, підвищити ऑiі технічний рівень i експортну конкурентоспроможність. Серед підприємств, які найбільш активно впроваджували інновації на Волині, можна відзначити: ТОВ «Модерн-Експо», ПАТ «СКФ Україна», ПрАТ «ВГП», ДП «Автоскладальний завод №1» АТ «АК «Богдан Моторс» та ПрАТ «Теріхем-Луцьк». 
Економічні науки: збірник наукових прачь Луцького національного технічного університету. - Серія "Регіональна економіка". - Випуск 16 (63). - Редкол.: відп. ред. д.е.н., професор Л.Л. Ковальська - Луцьк: ІВВ Луцького НТУ, 2019. - 173 с.

Загалом, на Волині обсяг експорту товарів у 2018 р. становив 720,1 млн. дол. США, імпорту - 1368,3 млн. дол. Порівняно із 2017 р. експорт збільшився на 4,5\% (на 30,8 млн.дол.), імпорт зріс на 2,5\% (на 32,9 млн. дол.). Зовнішньоторговельні операції проводились із партнерами 3 109 країн світу. Найбільші обсяги експорту товарів припали на Німеччину (26,7\% від загальнообласного експорту), Польщу $(21,1 \%)$, Нідерланди $(13,2 \%)$, Білорусь $(5,5 \%)$, Російську Федерацію (3,1\%), Італію (3,0\%), Австрію (2,4\%). Основу товарної структури експорту складали машини, обладнання та механізми; електротехнічне обладнання - 42,6\%, деревина i вироби $з$ деревини - 19,1\%, продукти рослинного походження $11,3 \%$, меблі - 7,3; продукти тваринного походження - 4,3\%, недорогоцінні метали та вироби 3 них - 2,7\%, текстильні матеріали та вироби $-2,5 \%$. Як бачимо зі структури експорту, $\epsilon$ чимало резервів для нарощення частки більш високотехнологічної продукції за рахунок продукції рослинного походження, деревини і виробів $з$ неї.

Розглядаючи рівень зайнятості населення Волині, слід підкреслити значний невикористаний потенціал, адже у 2015 р. частка зайнятості серед населення у віці $15-70$ рр. становила $53,1 \%$ зі зниженим цільовим орієнтиром 52\% у 2020 р. і досягнення $60 \%$ у 2030 р. Тому підвищення рівня зайнятості населення, в тому числі самозайнятості як суб'єктів середнього та малого підприємництва, може стати серйозним поштовхом розвитку області.

Станом на початок 2018 року на обліку в органах ДФС Волинської області перебувало 58124 юридичні та фізичні особи-підприємці. За 2017 рік частка надходжень від суб'єктів малого і середнього підприємництва області до бюджетів усіх рівнів склала 41,7\%, тоді як у 2015 році - 44,1\%. Для сприяння розвитку малого і середнього бізнесу в області реалізуються програми підтримки підприємництва на регіональному та місцевому рівнях. Розроблена Регіональна програма підтримки малого i середнього підприємництва в області на 20182020 роки, згідно 3 якою передбачається відшкодування 3 
Економічні науки: збірник наукових праџь Луцького національного технічного університету. - Серія "Регіональна економіка". - Випуск 16 (63). - Редкол.: відп. ред. д.е.н., професор Л.Л. Ковальська - Луцьк: ІВВ Луцького НТУ, 2019. - 173 с.

обласного бюджету відсоткових ставок за кредитами, залученими суб'єктами малого і середнього бізнесу для реалізації інвестиційних бізнес-планів, що реалізуються у пріоритетних галузях економіки області.

Служба зайнятості сприяла розгортанню підприємницької діяльності безробітними шляхом виплати одноразової допомоги по безробіттю для відкриття власної справи, яку отримують в тому числі демобілізовані учасники антитерористичної операції. На курсах цільового призначення за програмою «Підприємецьпочатківець» для організації підприємницької діяльності у 2017 році навчалася 141 особа, що, на нашу думку, досить мало.

Тому варто активніше створювати інституційні та фінансові можливості для самореалізації потенціалу економічно активної частини населення та розвитку креативної економіки і подальшого поступу у рейтингу легкості ведення бізнесу, зокрема, Doing Business, де наразі ми займаємо 64 сходинку.

Щодо завдання із сприяння забезпеченню надійних та безпечних умов праці для всіх працюючих, зокрема шляхом застосовування інноваційних технологій у сфері охорони праці та промислової безпеки, то його індикаторами є:

- кількість потерпілих від нещасних випадків на виробництві, які призвели до втрати працездатності на 1 робочий день чи більше, \% до рівня 2015 року 3 цільовим орієнтиром 75 (встановленим на 2020 рік) 3 фактичним показником на Волині 90 і в Україні 97 у 2018 році;

- кількість загиблих від нещасних випадків на виробництві (\% до рівня 2015 р.) - становила 77 у 2018 р. і 109 в середньому в Україні. Зважаючи на цільовий орієнтир 2020 р. у розмірі 70 - це завдання виконується недостатньо ефективно і має непоправні наслідки.

Підсумовуючи, наведемо базові рекомендації із досягнення цілі 8:

- створення умов для модернізації виробництва, розвитку інновацій, підвищення експортного потенціалу Волині;

- внесення до стратегічних документів місцевих громад проектів, що передбачають сталий розвиток регіону та 
Економічні науки: збірник наукових прачь Луцького національного технічного університету. - Серія "Регіональна економіка". - Випуск 16 (63). - Редкол.: відп. ред. д.е.н., професор Л.Л. Ковальська - Луцьк: ІВВ Луцького НТУ, 2019. - 173 с.

запровадження принципів зеленої економіки;

- активізація молоді в інноваційних проектах громад.

Ціль 9 - промисловість, інновації, інфраструктура передбачає створення стійкої інфраструктури, сприяння всеохоплюючій і сталій індустріалізації та інноваціям в регіоні.

Розвиток якісної, надійної і доступної інфраструктури повинен базуватися на широкому використанні інноваційних технологій, в т.ч. екологічно чистих видів транспорту. При цьому частка електротранспорту у внутрішньому сполученні в середньому в Україні у 2015 році становила 60,3\%, тоді як на Волині лише 6,5\% (вдесятеро менше)! Цільовий орієнтир, встановлений на 2020 рік в області - 6,7\% і планується його зростання до 8\% у 2030 році. Зазначимо, що такий низький порівняльний показник зумовлений тим, що в області електротранспорт $є$ лише у м. Луцьку (тролейбусне забезпечення), а частка електромобілів (переважно, це Nissan Leaf) наразі ще дуже низька. Зокрема, за 2018 рік на Волині зареєстровано 75 гібридів і 54 електрокари, а станом на 29 жовтня сервісні центри МВС на Волині вперше зареєстрували 92 гібриди та 146 електрокарів, тоді як у 2015 році їх було лише 8 одиниць [5]. Завдяки стрімкому зростанню цього ринкового сегменту, i на Волині в тому числі, Україна нині серед світових лідерів за темпами зростання електрокарів. 3 економічної точки зору, крім менших витрат на поточне обслуговування, цьому сприяють пільгове розмитнення таких ТЗ, відсутність ПДВ та акцизу.

Ще одним завданням задля досягнення цієї цілі визначено забезпечення доступності Інтернету, особливо у сільській місцевості. Фактичні значення наведено на рисунку 1, цільового орієнтиру у розмірі 50 абонентів на 100 жителів вже досягнуто як на загальнодержавному, так і на регіональному рівні.

Іншим завданням передбачається збільшення участі молоді, зокрема, дослідників до 40 років, у наукових дослідженнях. При цьому слід відзначити, що на Волині ця частка становить 46,8\% (після Кіровоградської, Сумської та Хмельницької областей) при загальноукраїнській $33,5 \%$ у 2018 році, тобто потенціал регіону у проведенні сучасних 
Економічні науки: збірник наукових прачь Луцького національного технічного університету. - Серія "Регіональна економіка". - Випуск 16 (63). - Редкол.: відп. ред. д.е.н., професор Л.Л. Ковальська - Луиьк: ІВВ Луцького НТУ, 2019. - 173 с.

наукових досліджень доволі високий.

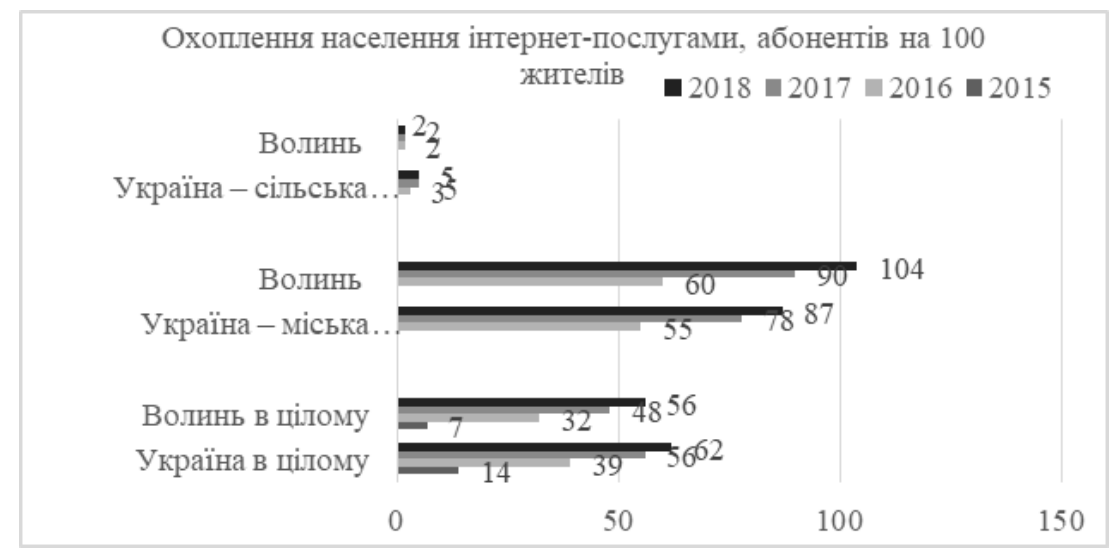

Рис. 1. Охоплення населення інтернет-послугами

Загальні рекомендації щодо досягнення цілі 9 із створення стійкої інфраструктури, сприяння всеохоплюючій і сталій індустріалізації та інноваціям в регіоні такі:

- забезпечення розробки i пріоритетного розвитку перспективних інноваційних проектів, що мають вирішальний вплив на ефективність і конкурентоспроможність економіки;

- удосконалення механізмів надання пільгових кредитів банків на впровадження інноваційних проектів;

- відновлення та розвиток наявного виробничотехнологічного i наукового потенціалу, формування міжрегіонального інноваційного ринку, наукоємного та інноваційного підприємництва;

- законодавче врегулювання сфери інтелектуальної власності з метою іiі комерціалізації (створення відповідного ринку);

- постійне оновлення бази даних нових технологій, інноваційних проектів та пошук потенційних інвесторів;

- розробка механізму щодо надання пільг підприємствам, які впроваджують інноваційну продукцію та новітні технології. 
Економічні науки: збірник наукових праць Луцького національного технічного університету. - Серія "Регіональна економіка". - Випуск 16 (63). - Редкол.: відп. ред. д.е.н., професор Л.Л. Ковальська - Луцьк: ІВВ Луцького НТУ, 2019. - 173 с.

При цьому стратегічно важливим кроком $є$ залучення провідних регіональних вищих навчальних закладів освіти до надання послуг інформаційно-довідкового, освітнього та експертно-консалтингового характеру.

Наступною із пріоритетних для Волинської області цілей сталого розвитку визначено ціль 15 щодо захисту та відновлення екосистем суші, зокрема, сприяння їх раціональному використанню, раціональне лісокористування, боротьба 3 опустелюванням, припинення i повернення назад процесу деградації земель та зупинка процесу втрати біорізноманіття.

Насправді це дуже важлива ціль, адже за одну годину гектар лісу поглинає весь обсяг вуглекислого газу, видихнутий 200 людьми за цей же час. Тому лісові площі варто нарощувати. Нині $31,5 \%$ області зайнято лісами і заплановане поступове зростання цієї частки до $34 \%$ у 2030 році.

Слід займатися також відновленням деградованих земель та грунтів, бажано з використанням інноваційних технологій. На Волині 7439,5 га земель $є$ деградованими або малопродуктивними. Тому набирає розповсюдження такий підхід як ревайлдінг (здичавіння ландшафтів або їх консервація без терміну придатності) як повернення земель до дикого стану шляхом їх самовідновлення 3 повним біорізноманіттям рослинного та тваринного середовища.

В контексті збалансування екологічних та економічних цілей сталого розвитку видається не простим завдання зі скорочення частки орних земель у загальній території області (з $33,4 \%$ у 2015 році до $31 \%$ вже у 2020 році, зважаючи на загальнодержавний орієнтир 51\%) одночасно із необхідністю економічного нарощення сільськогосподарського потенціалу регіону. Ще однією цікавою тенденцією за сучасних умов $є$ інтенсифікація органічного землеробства порівняно 3 традиційним i, очевидно, цей напрям приваблює профільні сільськогосподарські підприємства Волинського регіону. Україна входить в двадцятку країн у світі 3 найбільшим земельним банком під органічним виробництвом. Це складає лише $1 \%$ в загальній структурі с/г угідь (410550 га - площа 
Економічні науки: збірник наукових прачь Луцького національного технічного університету. - Серія "Регіональна економіка". - Випуск 16 (63). - Редкол.: відп. ред. д.е.н., професор Л.Л. Ковальська - Луцьк: ІВВ Луцького НТУ, 2019. - 173 с.

сертифікованої органічної землі), а на Волині сертифіковано понад 20 суб'єктів підприємницької діяльності на виробництво органічної продукції «Органік стандарт». Серед них ПП «ЗАХІД АГРО», ТОВ «Агрофрукт ЛТД», ТОВ «Біофрут», ТОВ «Дари Волині», ТОВ «Добрий сад» тощо [6].

Проте, групою міжнародних експертів з Технологічного університету Чалмерса (Гетеборг, Швеція) доведено, що органічне виробництво в середньому вдвічі швидше прискорює глобальне потепління, ніж продукція вироблена із використанням агрохімії. Оцінюючи вплив на клімат, вчені вперше враховували кількість вуглецю, використовуючи розроблений комплексний метричний показник «альтернативні вуглецеві витрати» (Carbon Opportunity Cost), яку могли б утримати ліси на тій площі землі, яку довелося відвести під поля. Відмова від агродобрив призводить до зниження врожайності, відповідно, доводиться використовувати значно більшу площу землі. «Наше дослідження показує, що органічний горох, що вирощується у Швеції, впливає на клімат приблизно на 50\% більше, ніж горох, вирощений у традиційних господарствах. Для деяких продуктів різниця ще відчутніша наприклад, у випадку з органічною озимою пшеницею вона досягає 70\%» [7; 8]. Цікавим також є той факт, що застосування біопалива може виявитися більш небезпечним для глобальної екосистеми, ніж викопне паливо. Аргумент той же: виробництво етанолу 3 пшениці, цукрового очерету i кукурудзи, або дизельного палива 3 рапсу, вимагає великих площ сільськогосподарських земель, так що сумарне навантаження на біосферу виявляється вище, ніж від застосування солярки i бензину. Біопаливо, вироблене з відходів, сильно перевершує по екологічності викопне паливо, проте потенціал його виробництва і застосування невеликий.

Таким чином, 3 кліматичної точки зору, для захисту та відновлення екосистем органічне сільське господарство та виробництво і подальше використання біопалива не ефективне.

Наступна пріоритетна ціль для Волині - це сприяння побудові миролюбного і відкритого суспільства в інтересах 
Економічні науки: збірник наукових праџь Луцького національного технічного університету. - Серія "Регіональна економіка". - Випуск 16 (63). - Редкол.: відп. ред. д.е.н., професор Л.Л. Ковальська - Луцьк: ІВВ Луцького НТУ, 2019. - 173 с.

сталого розвитку, забезпечення доступу до правосуддя для всіх i створення ефективних, підзвітних та заснованих на широкій участі інституцій на всіх рівнях.

При цьому розглядається кількість осіб, які звертаються за безоплатною правовою допомогою. I якщо у 2015 році на Волині ця цифра становила 1168 осіб, то у 2018 році 11247 осіб, тобто, десятикратне зростання. Найбільше задіяним є Регіональний центр 3 надання безоплатної вторинної правової допомоги у Волинській області, а окрім нього, у більшості районних центрів функціонують також відповідні бюро правової допомоги Міністерства юстиції України.

Завдання із розвитку партнерських відносин влади i бізнесу для досягнення цілей сталого розвитку має на всеукраїнському рівні за індикатор кількість проектів публічноприватного партнерства. Що цікаво, на Волині ця інформація не включена до цільових даних і не відслідковуються.

Можна відмітити тенденцію із зростання кількості послуг електронного врядування: із 170,2 тис. од. У 2015 році до планових 320 тис. од. у 2020 році. Загалом, пріоритетними напрямами електронного урядування області $є$ :

- упровадження і розвиток електронних адмінпослуг; розвиток електронної демократії; участь у формуванні національної політики у сфері електронного урядування;

- підвищення знань, вмінь i навичок публічних службовців, студентів ВНЗ Волині та представників ГО щодо застосування електронного урядування і електронної демократії;

- вдосконалення автоматизації органів виконавчої влади та місцевого самоврядування, ЦНАПів, підтримка і розвиток їх IT-інфраструктури.

В контексті нарощення масштабів децентралізації та створення ОТГ виникає потреба у забезпеченні безпеки i новоутворених громад, що планується реалізувати за допомогою створення центрів безпеки у кількості як мінімум 3 одиниць у 2020 році в рамках міжмуніципального співробітництва.

Висновки. Дослідження цільових орієнтирів сталого розвитку Волинської області продемонструвало системну роботу державних 
Економічні науки: збірник наукових праџь Луцького національного технічного університету. - Серія "Регіональна економіка". - Випуск 16 (63). - Редкол.: відп. ред. д.е.н., професор Л.Л. Ковальська - Луиьк: ІВВ Луцького НТУ, 2019. - 173 с.

органів влади, задіяних до виконання поставлених завдань та моніторингу відповідних індикаторів сталого розвитку. Разом 3 тим, найбільші труднощі виникають саме у збалансуванні економічних видатків/преференцій, екологічних наслідків та соціальних ефектів кожної із розглянутих цілей. Також видається необхідністю ширше залучення приватного бізнесу, як крупних його представників, так i більш дрібних гравців ринку, до інформування про регіональні проблеми 3 метою спільного їх вирішення, стимулювання довгострокових інвестицій в еко-орієнтовані та науково-місткі проекти, в тому числі на засадах публічно-приватного партнерства.

1. Про Цілі сталого розвитку України на період до 2030 року : Указ Президента України від 30.09.2019 № 722/2019 / Президент України. URL: https://zakon.rada.gov.ua/laws/show/722/2019 (дата звернення: 11.11.2019).

2. Національна доповідь «Цілі сталого розвитку: Україна 2017». Київ, 2018. URL: $\quad$ http://www.un.org.ua/images/SDGs NationalReportUA Web 1.pdf звернення: 11.11.2019).

3. Ц Цілі Сталого Розвитку: Волинь. Регіональна доповідь-2018. Луцьк, 2019. URL: https:/www.undp.org/content/dam/ukraine/docs/ SDGreports/UNDP_SDG_Volyn_v05.pdf_(дата звернення: 11.11.2019).

4. Цілі сталого розвитку - Україна 2019: моніторинговий звіт. Електронний ресурс. - Режим доступу: https://www.unicef.org/ukraine/media/ 1831/file/SDGforChildren_monitoring_Ukr.pdf (дата звернення: 11.11.2019).

5. На Волині зростає попит на електрокари та гібридні автомобілі. 27 червня 2019. URL: https://volynonline.com/na-volini-zrostaye-popit-na-elektrokari-tagibridni-avtomobili/ (дата звернення: 01.11.2019).

6. Органічне виробництво: нові можливості для бізнесу. Департамент агропромислового розвитку Волинської ОДА. URL: http:/agrovolyn.gov.ua/news/ organichne-virobnictvo-novi-mozhlivosti-dlya-biznesu-foto_(дата звернення: 01.11.2019).

7. Органічні продукти гублять біосферу планети. URL: http://milkua.info /uk/post/organicni-produkti-gublat-biosferu-planeti (дата звернення: 01.11.2019).

8. Stefan Wirsenius: personal page. URL: https://www.chalmers.se/en/staff/ Pages/stefan-wirsenius.aspx (дата звернення: 01.11.2019).

9. Волинчук Ю.В. Глобальні виміри сталого розвитку. Економічний форум. 2015. № 1. C. 159-165.

10. Волинчук Ю.В., Герасимяк Н.В. Державна підтримка підприємництва в Україні у контексті вимог сталого розвитку. Економічний форум. 2016. № 4. С. 1521. 